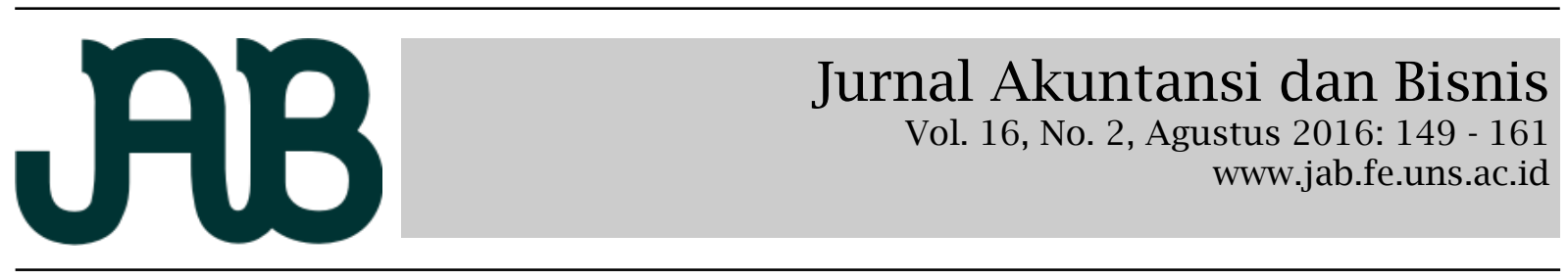

\title{
APAKAH PENYALURAN DANA DESA TERHAMBAT OLEH KARAKTERIS- TIK KEPALA DESA?
}

\section{R. RUDY KARYANTO}

Badan Pengawas Keuangan dan Pembangunan Republik Indonesia (BPKP-RI) Perwakilan Sumatera Utara

\begin{abstract}
A B S TR A C T
The government is trying to build state of the village with the Village Fund, but many assume that the head of the village there is less quality that is hindering its implementation. This study aims to find empirical evidence about the influence of the characteristic village head against the delivery timeliness accountability report progress in implementation of the Village Budget for the report as a condition of the Village Fund distribution. Factors tested in this study are age, years of education, and gender of the village head. This research was carried out on all village heads in Pati 2015. The sampling method used is purposive sampling method. These factors were then tested using logistic regression at the significance level of 5 percent. The results of the study identified that age and years of service does not affect the timeliness of the submission of accountability reports progress in implementation of Budget village. While education levels significantly negative impact on the timeliness of delivery Accountability Report Actual Budget Implementation and gender village headman positive and significant effect on the timeliness of the delivery of the Budget Implementation Realization Accountability Report PBDesa. The influence of the characteristics of the head of villages surveyed by 5.7 percent against the timeliness of report submission Accountability Actual Budget Implementation village.

Keywords: Timeliness, characteristic of village head, village fund and Village Budget Revenue and Expenditure (APBDesa)
\end{abstract}

Pemerintah berusaha untuk membangun desa dengan Dana Desa, tetapi banyak yang berasumsi bahwa kepala desa kurang berkualitas sehingga menjadi penghambat dalam pelaksanaanya. Penelitian ini bertujuan untuk menemukan bukti empiris mengenai pengaruh karakteristik kepala desa terhadap ketepatan waktu penyampaian laporan pertanggungjawaban realisasi pelaksanaan Anggaran Desa sebagai kondisi pendistribusian Dana Desa. Faktor-faktor yang diuji dalam penelitian ini adalah umur, tingkat pendidikan dan jenis kelamin kepala desa. Penelitian ini dilakukan pada semua kepala desa di Pati untuk tahun 2015. Metode pengambilan sampel yang digunakan adalah purposive sampling. Faktor-faktor tersebut kemudian diuji dengan menggunakan regresi logistik dengan tingkat signifikansi 5\%. Hasil penelitian menunjukkan bahwa usia dan masa kerja tidak mempengaruh ketepatan waktu penyampaian laporan pertanggingjawaban realisasi pelaksanaan anggaran desa. Sedangkan, tingkat pendidikan berpengaruh negatif signifikan terhadap ketepatwaktuan dalam penyampaian laporan pertanggungjawaban realisasi anggaran desa dan jenis kelamin berpengaruh positif signifikan tehadap ketepatwaktuan penyampaian laporan pertanggungjawaban realisasi anggaran desa. Pengaruh karakteristik kepala desa terhadap ketepatan waktu penyampaian laporan pertanggungjawaban realisasi anggaran desa yaitu sebesar 5,7\%.

Kata kunci: Ketepatan waktu, karakteristik kepala desa, dana desa, Anggaran Pendapatan dan Belanja Desa (APBDesa)

\section{PENDAHULUAN}

Dalam perjalanan ketatanegaraan Republik Indonesia, desa telah berkembang dalam berbagai bentuk sehingga perlu dilindungi dan diberdayakan. Pengaturan desa mengalami perubahan secara signifikan sejak disahkannya Undang-Undang Nomor 6 tahun 2014 tentang Desa (UU Desa) pada tanggal 15 Januari 2014. Hal ini berakibat pada sisi regulasi, dimana desa dan desa adat (atau yang disebut dengan nama lain) tidak lagi menjadi bagian dalam Undang- 
Undang Nomor 32 tahun 2004 tentang Pemerintahan Daerah. Desa-desa yang ada mengalami perubahan susunan dan pendekatan baru dalam tata cara penyelenggaraan pemerintahan dan pembangunannya. Undang-Undang Desa mengamanatkan kewenangan luas kepada desa di bidang penyelenggaraan pemerintahan desa, pelaksanaan pembangunan desa, pembinaan kemasyarakatan desa dan pemberdayaan masyarakat desa berdasarkan prakarsa masyarakat, hak asal usul dan adat istiadat desa (KPK 2015).

Keberagaman Desa atau sebutan lainnya diwadahi dalam Negara Kesatuan Republik Indonesia (NKRI) hal ini menunjukkan adanya pengakuan keberagaman dalam wadah keseragaman. Keseragaman dalam hal ini bukannya mendikte atau menghilangkan karakteristik desa atau sebutan lainnya, tetapi menfasilitasi pembangunan desa atau sebutan lainnya seiring dengan perkembangan jaman (Hamzah 2015).

Dalam UU Desa tersebut terdapat jaminan yang lebih pasti bahwa setiap desa akan menerima dana yang bersumber dari pemerintah melalui Anggaran Pendapatan dan Belanja Negara (APBN) yang diterimakan langsung dari pusat dengan nama Dana Desa (DD) dan yang melalui mekanisme Anggaran Pendapatan dan Belanja Daerah (APBD) yang dikenal dengan Alokasi Dana Desa (ADD) dan Bagi Hasil PDRD. Dana Desa yang dianggarkan dalam APBN Tahun 2016 adalah sebesar Rp46,982 Triliun. Sedangkan ADD dan Bagi Hasil PDRD sebesar Rp36,723 Triliun dan Rp2,650 Triliun. Sehingga jumlah total dari DD, ADD dan Bagi Hasil PDRD dalam APBN 2016 sebesar Rp86,356 Triliun (DJP 2015).

Berdasarkan data dari Kementerian Dalam Negeri jumlah Desa pada tahun 2015 sebanyak 74.903 (Permendagri No.39 tahun 2015) dan naik sebanyak 661 desa sehingga pada tahun 2016 sebanyak 74.754 desa (Permendagri No. 56 tahun 2015). Seluruh anggaran DD, ADD dan Bagi Hasil PDRD diatas akan diberikan kepada seluruh desa di Indonesia sehingga rata-rata per desa akan menerima sebesar Rp1,1 miliar.
Besarnya dana yang didapat oleh desa tersebut sebagai wujud dari "Nawa Cita" yang ketiga yaitu membangun indonesia dari pinggiran dengan memperkuat daerahdaerah dan desa dalam kerangka negara kesatuan. Konsekuensi dari kebijakan diatas terhadap proses pengelolaannya seharusnya dilaksanakan secara profesional, efektif dan efisien, serta akuntabel yang didasarkan pada prinsip-prinsip manejemen publik yang baik agar terhindarkan dari resiko terjadinya penyimpangan, penyelewengan dan korupsi. Oleh karena itu, pemerintah melalui Menteri Dalam Negeri mengeluarkan Peraturan Menteri Nomor 113 tahun 2014 tentang Pengelolaan Keuangan Desa. Dalam peraturan ini, pemerintah desa diwajibkan dapat mengelola keuangan desa berdasarkan asas-asas transparan, akuntabel, partisipatif serta dilakukan dengan tertib dan disiplin anggaran.

Penyaluran dana desa pada tahun anggaran 2016 sesuai dengan Peraturan Menteri Keuangan Nomor 49/PMK.07/2016 dilakukan dengan cara pemindahbukuan dari rekening kas umum negara (RKUN) ke rekening kas umum daerah (RKUD) untuk selanjutnya dilakukan pemindahbukuan dari RKUD ke rekening kas desa (RKD). Penyaluran dilakukan secara bertahap dengan ketentuan tahap I pada bulan Maret sebesar $60 \%$ (enam puluh persen) dan tahap II pada bulan Agustus sebesar 40\% (empat puluh persen). Penyaluran tahap I dilakukan setelah Bupati/Walikota telah menerima peraturan Desa mengenai APBDesa dan Laporan realisasi penggunaan Dana Desa tahun anggaran sebelumnya (Tahun Anggaran 2015).

Pemerintah menargetkan agar anggaran dalam APBN 2016 tersebut dapat segera tersalurkan ke seluruh desa. Dalam pelaksanaan penyaluran dana desa tahun 2015 menemui beberapa kendala diantaranya pemerintah desa belum memiliki rekening kas desa, tidak adanya perbankan yang menjangkau hingga ke pelosok dan pemerintah daerah belum/lambat dalam menyampaikan laporan penggunaan dana desa yang sudah diterima sebelumnya sehingga mengakibatkan proses penyaluran ke seluruh desa pada tahap selanjutnya 
tidak berjalan dengan baik. Pada penyaluran dana desa tahap ketiga, ditemui juga kendala sebagaimana disampaikan oleh Kementerian Keuangan (Kemenkeu) yang menyebutkan, penyaluran dana desa tahap ketiga terancam batal direalisasikan. Penyebabnya banyak daerah yang belum melaporkan 100 persen penyerapan dana desa untuk tahap satu dan tahap dua yang sudah dikirimkan pemerintah pusat (Kusuma 2015).

Selain itu, dengan kurangnya pengetahuan yang dimiliki, kepala desa takut dalam menggunakan dana desa sebagaimana disampaikan oleh Menteri Desa, Pembangunan Daerah Tertinggal dan Transmigrasi, Marwan Jafar, menegaskan, kepala desa di seluruh Indonesia tidak perlu takut menggunakan dana desa. Marwan kembali menegaskan hal ini mengingat realisasi dana desa masih rendah lantaran sejumlah kepala desa takut menggunakannya dana desa sehingga proses pelaporan menjadi terhambat (Thenu 2016).

Pemerintahan desa yang merupakan wujud pemerintahan terendah dalam ketatanegaraan di Republik Indonesia sering dianggap bahwa desa dikelola oleh orangorang yang memiliki kompetensi yang rendah sehingga banyak yang meragukan kemampuan kepala desa dalam mendukung keberhasilan program dana desa yang dibuat oleh pemerintah pusat. Anggapan itu dirasa tidak semuanya salah, hal ini tercermin dalam Undang-undang Desa itu sendiri yang membuat persyaratan dalam pencalonan baik kepala desa maupun perangkat desa dengan kriteria yang sederhana agar dapat dipenuhi oleh masyarakat yang tinggal di desa.

Dalam laporan kajian terhadap sistem pengelolaan keuangan desa yang dilakukan oleh Deputi Bidang Pencegahan Komisi Pemberantasan Korupsi juga menyimpulkan bahwa terdapat potensi masalah dalam Sumber Daya Manusia dalam pengelolaan keuangan desa yang diakibatkan oleh kelemahan aparat desa.

Wujud akuntabilitas dalam pengelolaan dana desa adalah adanya kewajiban penyusunan laporan pertanggungjawaban oleh pemerintah desa. Dalam Peraturan
Pemerintah (PP) Nomor 43 tahun 2014 pasal 103 dan 104 mengatur tata cara pelaporan yang harus dilakukan oleh Kepala Desa, yaitu menyampaikan laporan realisasi pelaksanaan APBDes kepada Bupati/Walikota setiap semester tahun berjalan (laporan semesteran), menyampaikan laporan pertanggungjawaban realisasi pelaksanaan APBDes kepada bupati/ walikota setiap akhir tahun anggaran (laporan tahunan) dan Laporan pertanggungjawaban yang harus dibuat oleh Kepala Desa telah terintegrasi secara utuh, tidak melihat sumber dana yang diperoleh desa. Batas akhir penyampaian laporan pertanggungjawaban realisasi pelaksanaan APBDesa tahun 2015 kepada Bupati adalah 31 Januari 2016.

Selain sebagai wujud akuntabilitas, laporan tersebut merupakan salah satu persyaratan dalam penyaluran dana desa untuk tahun anggaran 2016 dari RKUD ke RKD. Sehingga ketepatwaktuan penyampaian laporan tersebut sangat penting untuk kelangsungan penyaluran dana desa. Menurut Kepala Badan Pemberdayaan Masyarakat Desa (Bapermades) Kabupaten Pati, Muhtar, jumlah desa yang sudah menyampaikan LKPJ, LPPD dan selesai SPJ 2015 dalam rangka penyaluran Alokasi Dana Desa dan Dana Desa 2016 sebesar tiga puluh persen (Patikab.go.id 2016).

Kondisi kepala desa yang hampi sama dengan saat penyaluran dana desa tahun 2015, dimana terdapat kendala dalam penyalurannya yang diakibatkan oleh keterlambatan penyampaian laporan pertanggungjawaban dana desa, mengingat variatifnya karakteristik kepala desa dari segi usia, masa kerja, jenjang pendidikan dan gender kepala desa dimungkinkan mempengaruhi dalam penyusunan laporan pertanggungjawaban realisasi pelaksanaan APBDes tahun 2015 sehingga mempengaruhi ketepatwaktuan penyampaian laporan pertanggungjawaban realisasi pelaksanaan APBDes tahun 2015.

Peneliti termotivasi melakukan penelitian ini karena belum adanya peneliti yang melakukan terkait ketepatwaktuan penyampaian laporan pertanggungjawaban realisasi pelaksanaan APBDes tersebut. Hal ini karena pelaksanaan pengelolaan keu- 
angan desa pada tahun 2015 merupakan tahun anggaran yang pertama dalam pelaksanaan UU Desa dan regulasi pelaksanaan pemerintahan desa lainnya. Selain itu, dari penelitian yang telah dilakukan oleh Winidyaningrum dan Rahmawati (2010) dan Andriani (2010) mengenai ketepatwaktuan pelaporan keuangan pemerintah daerah menunjukkan bahwa sumber daya manusia memiliki pengaruh positif tidak signifikan, sehingga bertentangan dengan pemberitaan yang ada yang mengabarkan bahwa keterlambatan pelaporan dana desa diakibatkan oleh rendahnya sumber daya manusia pengelolanya.

Dalam laporan kajian terhadap sistem pengelolaan keuangan desa yang dilakukan oleh Deputi Bidang Pencegahan Komisi Pemberantasan Korupsi juga menyimpulkan bahwa terdapat potensi masalah dalam Sumber Daya Manusia dalam pengelolaan keuangan desa yang diakibatkan oleh kelemahan aparat desa (KPK 2015). Berdasarkan hal tersebut, maka permasalah dalam penelitian ini adalah Apakah terdapat pengaruh karakteristik kepala desa terhadap ketepatwaktuan penyampaian Laporan Pertanggungjawaban Realisasi Pelaksanaan Anggaran Pendapatan dan Belanja Desa?

Ketepatwaktuan penyampaian Laporan Pertanggungjawaban Realisasi Pelaksanaan Anggaran Pendapatan dan Belanja Desa memiliki pengaruh sangat besar terhadap kelancaran penyaluran Dana Desa dimana laporan tersebut digunakan sebagai syarat dalam pencairan Dana Desa tahun selanjutnya. Sedangkan kepala desa berkewajiban menyampaikan laporan sebagai penanggungjawab APBDesa. Oleh karena itu, kepala desa sangat memiliki peran dalam ketepatwaktuan penyampaian laporan. Sehingga atas dasar uraian tersebut, penelitian ini bertujuan untuk mencari bukti empiris karakteristik kepala desa memiliki pengaruh atas terhadap ketepatwaktuan penyampaian Laporan Pertanggungjawaban Realisasi Pelaksanaan Anggaran Pendapatan dan Belanja Desa.

\section{TINJAUAN PUSTAKA DAN PNGEM- BANGAN HIPOTESIS}

Menurut Hambrick dan Mason (1984), melalui Upper Echelon Theory, menyatakan bahwa strategi yang dipilih pemimpin merupakan refleksi atau cerminan dari nilai-nilai dan kognitif mereka. Karakteristik pimpinan puncak (upper echelon) sangat mewarnai arah atau pilihan strategi (strategic choice) mereka dan pada akhirnya menentukan kinerja organisasi. Teori ini menunjukkan usia, pengalaman, pendidikan, latar belakang sosial, kondisi ekonomi dan karakteristik kelompok dimana dia berada, merupakan filter pada saat mereka mencerna, menganalisis, dan mencoba memahami anatomi permasalahan. Hal tersebut menentukan kemampuan mereka menafsirkan situasi yang kompleks dan dengan cara apa situasi tersebut harus dikelola.

Menurut Lubis (2010), peran manajer di suatu organisasi penting karena adanya kebutuhan koordinasi dan kendali. Selain itu, ia juga mendefinisikan manajer sebagai seseorang yang bekerja melalui orang lain dengan mengkoordinasikan kegiatankegiatan pekerjaan untuk mencapai tujuan organisasi.

Peran seorang manajer sangat erat dengan keputusan-keputusan yang diambilnya dalam melakukan koordinasi dan kendali organisasi. Peran seorang manajer akan sesuai juga dengan tingkatan manajer yang melekat padanya. Lubis (2010) menjelaskan bahwa manajer secara umum terdiri dari tiga tingkatan yaitu manajer tingkat bawah, menengah dan atas.

1. Manajer Tingkat Bawah (Lower Management)

Manajer tingkat ini merupakan manajer yang menduduki tingkatan paling bawah dan mengelola pekerjaan individu non-manajerial yang terlibat dalam produksi atau penciptaan produk organisasi.

2. Manajer Tingkat Menengah (Middle Management)

Manajer ini berada antara tingkatan manajer tingkatan bawah dan tingkat puncak pada organisasi. Manajer tingkat menengah mengelola pekerjaan para manajer lini pertama.

3. Manajer Tingkat Atas (Top Management) 
Manajer ini menduduki posisi yang biasa disebut manajer puncak, yang bertanggung jawab atas pengambilan keputusan yang mencakup seluruh organisasi dan menyusun rencana serta sasaran yang akan mempengaruhi keseluruhan organisasi.

Peran manajer dalam mengambil keputusan yang kompleks sebagian besar dipengaruhi oleh faktor-faktor keperilakuan manajer (Cyret dan March 1963 serta March dan Simon 1958 dalam Hambrick dan Mason 1984). Menggunakan istilah pemilihan strategis (strategic choice) dalam pengambilan keputusan kompleks, Hambrick dan Mason (1984) menjelaskan bahwa aspek keperilakuan memiliki komponen terbesar dalam pemilihan strategis.

Esteve et al. (2012) mengembangkan upper echelons theory pada sektor publik, pada penelitiannya Esteve et al. (2012) mencoba mencerminkan karakter manajer sektor publik dari usia, masa kerja, latar pendidikan formal, jejak fungsional (pelatihan), pengembangan diri manajer dan gender.

Pemegang kekuasaan di desa yang merupakan sebuah pemerintahan terendah dalam tatanegara di Indonesia adalah seorang kepala desa. Kepala desa yang memiliki tanggungjawab untuk mengatur perangkat desa dalam proses pemerintahannya sangat menjadi kunci keberhasilan kepemimpinannya. Salah satu wujud tanggungjawab kepala desa yaitu sebagai pemegang kekuasaan pengelolaan keuangan desa. Pada pengelolaan keuangan desa yang ada saat ini, ketepatwaktuan penyampaian laporan pertanggungjawaban realisasi pelaksanaan APBDesa menjadi sorotan karena hal itu berpengaruh pada proses pengelolaan keuangan desa tahun anggaran selanjutnya. Oleh karena itu, kepala desa yang menjadi motor dalam pengelolaan keuangan desa sangat diperhatikan oleh masyarakat. Dengan banyaknya pemberitaan bahwa proses penyaluran dana desa yang tersendat dikarenakan kepala desa yang terlambat menyampaikan laporan pertanggungjawaban, maka karakteristik kepala desa yang mempengaruhi ketepatwaktuan menjadi sesuatu hal yang menarik untuk diketahui.
Kepala Desa atau yang disebut dengan nama lain merupakan kepala Pemerintahan Desa yang memimpin penyelenggaraan Pemerintahan Desa. Dalam UU Desa, Kepala desa didefinisikan sebagai Pejabat Pemerintah Desa yang mempuyai wewenang, tugas dan kewajiban untuk menyelenggarakan rumah tangga Desanya dan melaksanakan tugas dari Pemerintah dan Pemerintah Daerah. Kepala Desa tidak bertanggung jawab kepada Camat, namun hanya dikoordinasikan saja oleh Camat. Kepala Desa sebagai penanggung jawab dari pengelolaan keuangan desa secara keseluruhan. Dalam PP No. 43 tahun 2014 pasal 103-104 mengatur tata cara pelaporan yang wajib dilakukan oleh Kepala Desa. Kepala Desa diwajibkan menyampaikan laporan realisasi pelaksanaan APBDesa kepada Bupati/Walikota setiap semester tahun berjalan (laporan semesteran). Selain itu, Kepala Desa juga diwajibkan menyampaikan laporan pertanggungjawaban realisasi pelaksanaan APBDesa kepada bupati/walikota setiap akhir tahun anggaran (laporan tahunan). Laporan yang dibuat oleh Kepala Desa ditujukan kepada Bupati/Walikota yang disampaikan melalui camat.

Sesuai dengan UU Desa yang mensyaratkan usia calon kepala desa paling rendah 25 (dua puluh lima) tahun, diharapkan bahwa penduduk yang menjabat sebagai kepala desa merupakan penduduk yang sudah dewasa. Sehingga semakin dewasa seseorang maka akan semakin bertanggungjawab terhadap semua tindakantindakannya. Namun studi yang ada menunjukkan hasil yang konsisten bahwa munculnya manajer muda berhubungan dengan pertumbuhan perusahaan (Child 1974; Hart dan Mellons 1970 dalam Hambrick dan Mason 1984). Hambrick dan Manson (1984) mengungkapkan bahwa usia manajer berhubungan terbalik dengan kemampuan untuk mengintegrasikan informasi dan kepercayaan diri dalam mengambil keputusan. Oleh karena itu, hipotesis yang diajukan dalam penelitian ini adalah:

H1: Usia kepala desa memiliki pengaruh negatif terhadap ketepatwaktuan penyampaian laporan pertanggungjawa- 
ban realisasi pelaksanaan APBDesa

Masa kerja dari seseorang sangat ditentukan oleh rentan waktu lamanya seseorang menjalani pekerjaan tertentu. Lamanya pekerja tersebut dapat dilihat dari banyaknya tahun, yaitu sejak pertama kali diangkat menjadi kepala desa hingga penelitian ini dilakukan. Semakin lama masa kerja kepala desa akan memberikan lebih banyak pengalaman dan pengetahuan. Pengalaman dan pengetahuan tersebut juga terkait pengelolaan keuangan desa yang akhirnya membuat semakin cepat dalam penyusunan laporan pertanggungjawabannya. Oleh karena itu, hipotesis yang diajukan dalam penelitian ini adalah:

H2: Masa kerja kepala desa memiliki pengaruh positif terhadap ketepatwaktuan penyampaian laporan pertanggungjawaban realisasi pelaksanaan APBDesa

Dengan persyaratan kepala desa sesuai dengan UU Desa yang mengharuskan seoarang kepala desa dijabat oleh orang yang setidaknya telah menyelesaikan jenjang pendidikan dasar. Tujuan tingkat pendidikan satuan dasar adalah meletakkan dasar kecerdasan pengetahuan, kepribadian, akhlak mulia serta keterampilan untuk hidup mandiri dan mengikuti pendidikan lebih lanjut (UU 20/2003). Berdasar tujuan tersebut, diharapkan seorang kepala desa sudah memiliki kecerdasan pengetahuan, kepribadian, akhlak mulia dan keterampilan untuk hidup mandiri sehingga semakin tinggi jenjang pendidikan yang diselesaikan oleh seorang kepala desa maka semakin tinggi pula kinerjanya. Salah satu wujud kinerja dari seoarng kepala desa adalah penyampaian laporan pertanggungjawaban yang tepat waktu. Oleh karena itu, hipotesis yang diajukan dalam penelitian ini adalah:

H3: Jenjang pendidikan kepala desa memiliki pengaruh positif terhadap ketepatwaktuan penyampaian laporan pertanggungjawaban realisasi pelaksanaan APBDesa

Penelitian yang dilakukan CollinsDodd et al. (2004) mengungkapkan bahwa motivasi perempuan tentang karir dan keluarga memiliki hasil positif terhadap kinerja keuangan. Selain itu dari hasil penelitian oleh Jalbert et al. (2013) menunjukkan manajer perempuan cenderung memiliki kinerja keuangan yang lebih baik dibanding manajer laki-laki Oleh karena itu, hipotesis yang diajukan dalam penelitian ini adalah:

H4: Kepala Desa dengan gender perempuan memiliki pengaruh positif terhadap ketepatwaktuan penyampaian laporan pertanggungjawaban realisasi pelaksanaan APBDesa

\section{METODE PENELITIAN}

Penelitian ilmiah ini menggunakan metode penelitian kuantitatif. Menurut Sugiyono (2014) penelitian kuantitatif diartikan sebagai metode penelitian yang berlandaskan pada filsafat positivisme, digunakan untuk meneliti pada populasi atau sampel tertentu, pengumpulan data menggunakan instrumen penelitian, analisis data bersifat kuantitatif/statistik, dengan tujuan untuk menguji hipotesis yang telah ditetapkan.

Populasi yang menjadi subjek pengamatan dalam penelitian ini adalah populasi kepala desa di kabupaten Pati Tahun Anggaran 2015, dengan total Kepala Desa yang ada sebanyak 401 orang. Dalam menentukan sampel, penulis menggunakan terknik purposive sampling dengan kriteria sebagai berikut:

1. Kepala Desa merupakan penanggungjawab dalam pelaksanaan APBDesa 2015 dengan ditandai pelantikannya sebelum tahun anggaran berakhir (31 Desember 2015).

2. Bukan merupakan Pelaksana tugas (Plt), Pelaksana harian (Plh), Pejabat (Pj), maupun Pejabat sementara (Pjs) dari Kepala Desa.

3. Terdapat data yang lengkap untuk pengukuran variabel yang mencakup usia, latar belakang pendidikan, masa kerja, jenjang pendidikan dan gender Kepala Desa.

4. Kepala Desa menyampaikan Laporan Pertanggungjawaban Realisasi Pelaksanaan Anggaran Pendapatan dan Belanja Desa Tahun 2015. 
Penelitian ini menggunakan 5 (lima) variabel dalam pengujian hipotesisnya. Penelitian ini menggunakan satu variabel dependen dan empat variabel independen. Variabel dependen yang digunakan dalam penelitian ini adalah ketepatwaktuan penyampaian Laporan Pertanggungjawaban Realisasi Pelaksanaan APBDesa dan pengukuran Ketepatwaktuan penyampaian Laporan dengan menggunakan skala " 1 " untuk yang tepat waktu dan skala " 0 " untuk yang tidak tepat waktu.

Sedangkan variabel independen, yaitu usia kepala desa, masa kerja kepala desa, jenjang pendidikan kepala desa dan gender kepala desa. Pengukuran usia menggunakan Skala Interval, dimana skala 1 untuk usia 25 - 35 tahun, skala 2 untuk usia 36 - 45 tahun, skala 3 untuk usia 46 55 tahun, skala 4 untuk usia 56 - 65 tahun dan skala 5 untuk usia lebih dari 66 tahun. Pengukuran masa kerja dinyatakan dengan jumlah periode jabatan masing-masing kepala desa yaitu skala 1 untuk periode jabatan pertama kali, skala 2 untuk periode jabatan kedua dan sekala 3 untuk periode jabatan yang ketiga. Pengukuran jenjang pendidikan dinilai dengan menggunakan skala interval, yaitu skala 1 untuk lulusan SMP/sederajat, skala 2 untuk lulusan SMA/ sederajat, skala 3 untuk lulusan Diploma, Skala 4 untuk lulusan Strata 1 (S1), Skala 5 untuk lulusan Magister (S2) dan skala 6 untuk lulusan Doktoral (S3). Pengukuran gender laki-laki diwakilkan dengan angka "1" sedangkan gender perempuan diwakilkan dengan angka "2".

Jadi dalam artikel ini penulis berupaya memberikan bukti ada/tidaknya pengaruh dari karakteristik kepala desa terhadap ketepatwaktuan penyampaian laporan untuk membuktikan kebenaran anggapan masyarakat bahwa kepala desa yang ada saat ini menjadi penghambat dalam penyaluran dana desa yang sedang menjadi prioritas pemerintah.

\section{ANALISIS DAN PEMBAHASAN}

Tujuan dari penelitian yang dilakukan adalah untuk memberikan bukti empiris tentang pengaruh karakteristik kepala desa yang terdiri dari usia, masa kerja, jenjang pendidikan dan gender terhadap ketepatwaktuan penyampaian laporan pertanggungjawaban realisasi pelaksanaan APBDesa tahun 2015. Penelitian ini menggunakan uji regresi logistik dengan telah memenuhi kelayakan model regresi, uji multikolinearitas, Omnibus Test of Model Coefficient, dan keseluruhan model sudah fit. Sehingga model dapat dilakukan perhitungan koefisien determinasi dan uji parsial. Hasil dari perhitungan koefisien determinasi $\left(\mathrm{R}^{2}\right)$ menunjukkan bahwa variabel dependen dipengaruhi variabel independen sebesar 5,7\%. Sedangkan untuk hasil Uji Parisal disajikan dalam tabel 1.

\section{Tabel 1}

Hasil Uji Parsial

\begin{tabular}{lcrccccc}
\hline & & B & S.E. & Wald & df & Sig. & $\begin{array}{c}\text { Exp } \\
\text { (B) }\end{array}$ \\
\hline Step & AGE & 0,065 & 0,121 & 0,283 & 1 & 0,595 & 1,067 \\
$1^{\text {a }}$ & WRP & 0,270 & 0,228 & 1,408 & 1 & 0,235 & 1,310 \\
& EDU & $-0,355$ & 0,117 & 9,283 & 1 & 0,002 & 0,701 \\
& GDR & 1,044 & 0,370 & 7,951 & 1 & 0,005 & 2,841 \\
& $\begin{array}{l}\text { Con- } \\
\text { stant }\end{array}$ & $-1,125$ & 0,592 & 3,608 & 1 & 0,057 & 0,325 \\
\hline
\end{tabular}

Variable(s) entered on step 1: AGE, WRP, EDU, GDR.

Berdasarkan hasil tabel 1, statistik Wald untuk variabel usia kepala desa (AGE) adalah sebesar 0,283, sedangkan dari tabel Chi-Square untuk tingkat signifikan 5\% atau 0,05 dan derajat bebas $(\mathrm{df})=1$ diperoleh hasil 3,841. Dapat disimpulkan bahwa usia kepala desa tidak berpengaruh terhadap ketepatwaktuan penyampaian Laporan Pertanggungjawaban Realisasi Pelaksanaan APBDesa.

Untuk variabel masa kerja kepala desa (WRP) hasil tabel 1, statistik Wald adalah sebesar 1,408, sedangkan dari tabel ChiSquare untuk tingkat signifikan 5\% atau 0,05 dan derajat bebas $(\mathrm{df})=1$ diperoleh hasil 3,841. Dapat disimpulkan bahwa masa kerja kepala desa tidak berpengaruh terhadap ketepatwaktuan penyampaian Laporan Pertanggungjawaban Realisasi Pelaksanaan APBDesa.

Untuk variabel jenjang pendidikan kepala desa (EDU) hasil tabel di atas, statistik Wald adalah sebesar 9,283, sedangkan dari tabel Chi-Square untuk tingkat signifikan $5 \%$ atau 0,05 dan derajat bebas $(\mathrm{df})=1$ diperoleh hasil 3,841. Hal tersebut menun- 
jukkan bahwa variabel jenjang pendidikan berpengaruh terhadap variabel dependen. Berdasar hasil pengujian, Nilai B dari variabel jenjang pendidikan sebesar $-0,355$. Oleh karena nilai B bersifat negatif, maka variabel jenjang pendidikan mempunyai hubungan negatif terhadap variabel dependen. Sedangkan nilai sig hasil pengujian variabel jenjang pendidikan (EDU) adalah sebesar 0,004, nilai sig tersebut lebih kecil dari tingkat signifikansi yang ditentukan sebesar 0,05, menunjukkan bahwa variabel jenjang pendidikan (EDU) memiliki pengaruh signifikan. Sehingga dapat disimpulkan bahwa jenjang pendidikan kepala desa berpengaruh negatif secara signifikan terhadap ketepatwaktuan penyampaian Laporan Pertanggungjawaban Realisasi Pelaksanaan APBDesa.

Untuk variabel gender kepala desa (GDR) hasil tabel 1, statistik Wald adalah sebesar 7,951, sedangkan dari tabel ChiSquare untuk tingkat signifikan 5\% atau 0,05 dan derajat bebas $(\mathrm{df})=1$ diperoleh hasil 3,841. Hal tersebut menunjukkan bahwa variabel gender berpengaruh terhadap variabel dependen. Berdasar hasil pengujian, Nilai B dari variabel gender sebesar 1,044. Oleh karena nilai B bersifat positif, maka variabel gender mempunyai hubungan positif terhadap variabel dependen. Sedangkan hasil pengujian variabel gender (GDR) memiliki nilai sig sebesar 0,004, nilai sig tersebut lebih kecil dari tingkat signifikansi yang ditentukan sebesar 0,05, menunjukkan bahwa variabel gender (GDR) memiliki pengaruh signifikan. Sehingga dapat disimpulkan bahwa gender (GDR) kepala desa berpengaruh positif secara signifikan terhadap ketepatwaktuan penyampaian Laporan Pertanggungjawaban Realisasi Pelaksanaan APBDesa.

Berdasarkan nilai-nilai B pada hasil perhitungan yang disajikan pada tabel 1 , maka model persamaan yang dibentuk adalah sebagai berikut:

Tujuan utama penyampaian Laporan Pertanggungjawaban Realisasi Pelaksanaan APBDesa adalah wujud akuntabilitas dari pengelolaan keuangan desa yang kepala desa sebagai penanggungjawab APBDesa. Berdasarkan hasil penelitian yang dilakukan, diketahui bahwa karakteristik kepala desa yang terdiri dari usia (AGE), masa kerja (WRP), jenjang pendidikan (EDU) dan gender (GDR) berpengaruh secara bersama-sama terhadap ketepatwaktuan penyampaian Laporan Pertanggungjawaban Realisasi Pelaksanaan APBDesa. Dalam rangka peningkatan kualitas pengelolaan keuangan desa, khususnya peningkatan ketepatwaktuan penyampaian Laporan Pertanggungjawaban Realisasi Pelaksanaan APBDesa, pada seluruh desa di kabupaten Pati agar pimpinan instansi yang memiliki tanggungjawab pembinaan terhadap kepala desa dapat memperhatikan empat faktor tersebut. Sehingga masing-masing kepala desa dapat menyampaikan laporannya tepat waktu sesuai UU Desa. Penelitian ini mencoba memberikan bukti empiris mengenai hal tersebut yaitu relevansi karakteristik kepala desa terhadap ketepatwaktuan penyampaian Laporan Pertanggungjawaban Realisasi Pelaksanaan APBDesa.

\section{Usia Kepala Desa dan Ketepatwaktuan Penyampaian Laporan Pertanggungjawa- ban Realisasi Pelaksanaan APBDesa}

Berdasarkan hasil pengujian secara parsial menunjukkan bahwa usia kepala desa tidak berpengaruh terhadap ketepatwaktuan penyampaian Laporan Pertanggungjawaban Realisasi Pelaksanaan APBDesa. Hal ini terlihat dari nilai statistik Wald pengujian sebesar 0,283, sedangkan dari tabel ChiSquare untuk tingkat signifikan $5 \%$ atau 0,05 dan derajat bebas (df) $=1$ diperoleh hasil 3,841. Oleh sebab itu, hipotesis (H1) yang diajukan ditolak.

Hasil penelitian yang dilakukan menunjukkan bahwa usia kepala desa tidak berpengaruh terhadap ketepatwaktuan penyampaian laporan, sehingga baik kepala desa yang berusia muda maupun kepala desa yang berusia lebih tua dalam menyampaikan laporan pertanggungjawaban ralisasi pelaksanaan APBDesa banyak yang tidak tepat waktu. hal ini terjadi mungkin dipengaruhi tidak adanya kompensansi dan motivasi dari kepala desa untuk menyelesaikan laporan tepat pada waktunya. Dalam pelaksanaan tugas sebagai kepala desa untuk membuat sebuah 
laporan masih sangat tergantung dari informasi yang disampaikan oleh pejabat yang lebih tinggi (camat). Hal ini terkait loyalitas kepala desa kepada atasan. Menurut Ariyanti (2012), menyatakan bahwa kompensasi dan motivasi memiliki pengaruh yang signifikan terhadap loyalitas. Sehingga untuk meningkatkan loyalitas kepala desa dibutuhkan motivasi dan kompensasi dari pejabat yang lebih tinggi (camat atau bupati).

Dalam memperoleh informasi terbaru tentang aturan, kepala desa lebih mengandalkan informasi langsung dari instansi yang lebih tinggi (baik kecamatan maupun kabupaten), menjadikannya kurang berani dalam mengambil resiko dan keputusan yang dihasilkan kurang tepat waktu. Sehingga berdampak pada penyampaian Laporan Pertanggungjawaban Realisasi Pelaksanaan APBDes yang disampaikan tidak tepat waktu.

\section{Masa Kerja Kepala Desa dan Ketepatwak- tuan Penyampaian Laporan Pertanggung- jawaban Realisasi Pelaksanaan APBDesa}

Berdasarkan hasil penelitian terhadap variabel masa kerja diperoleh nilai statistik Wald adalah sebesar 1,408, sedangkan dari tabel Chi-Square untuk tingkat signifikan $5 \%$ atau 0,05 dan derajat bebas $(\mathrm{df})=1$ diperoleh hasil 3,841. Dapat disimpulkan bahwa masa kerja kepala desa tidak berpengaruh terhadap ketepatwaktuan penyampaian Laporan Pertanggungjawaban Realisasi Pelaksanaan APBDesa, sehingga hipotesis (H2) ditolak.

Hasil pengujian terhadap variabel masa kerja kepala desa (WRP) ini tidak sesuai dengan pendapat Gomes et al. (2013) yang menyatakan bahwa manajer publik dengan pengalaman yang lebih banyak tentunya akan lebih dianjurkan karena manajer kaya pengalaman akan membuat keputusan yang lebih tepat.

Pengambilan keputusan dari seorang kepala desa sangat terkait dengan kebijakan yang dikeluarkan oleh pejabat di atasnya. Kebijakan-kebijakan tersebut menentukan langkah yang harus dilaksanakan oleh seorang kepala desa. Berdasar data yang diperoleh dilapangan, terindikasi adanya kebijakan pihak kecamatan dalam menentukan sendiri batas akhir penyampaian laporan dari kepala desa. Hal dapat memicu ketidaktepatan waktu penyampaian laporan oleh kepala desa. Selain itu, sosialisasi aturan terbaru terkait UU Desa oleh Bagian Pemerintahan kabupaten dilaksanakan pada akhir batas penyampaian laporan (minggu ke 2 januari).

Hal lain yang mengakibatkan banyaknya keterlambatan dalam penyampaian laporan oleh kepala desa adalah dalam proses penyusunan laporan kepala desa masih menggunakan cara manual. Hal ini dikarenakan kabupaten Pati pada tahun anggaran 2015 belum memiliki aplikasi atau program yang dapat digunakan untuk merencanakan, melaksanakan, melaporkan dan mengawasi APBDesa yang ada. Sehingga proses penyusunan laporan pertanggungjawaban ralisasi pelaksanaan APBDesa sangat memakan waktu dan berdampak pada banyaknya desa yang menyampaikan laporan terlambat.

\section{Jenjang Pendidikan Kepala Desa dan Ketepatwaktuan Penyampaian Laporan Pertanggungjawaban Realisasi Pelaksa- naan APBDesa}

Variabel jenjang pendidikan kepala desa (EDU) dari hasil tabel 1, memperlihatkan nilai statistik Wald-nya sebesar 9,283, sedangkan dari tabel Chi-Square untuk tingkat signifikan 5\% atau 0,05 dan derajat bebas $(\mathrm{df})=1$ diperoleh hasil 3,841. Hal tersebut menunjukkan bahwa variabel jenjang pendidikan berpengaruh terhadap variabel dependen. Berdasar hasil pengujian, Nilai B dari variabel jenjang pendidikan sebesar -0,355. Oleh karena nilai B bersifat negatif, maka variabel jenjang pendidikan mempunyai hubungan negatif terhadap variabel dependen. Sedangkan nilai sig hasil pengujian variabel jenjang pendidikan (EDU) adalah sebesar 0,004, nilai sig tersebut lebih kecil dari tingkat signifikansi yang ditentukan sebesar 0,05, menunjukkan bahwa variabel jenjang pendidikan (EDU) memiliki pengaruh signifikan. Sehingga dapat disimpulkan bahwa jenjang pendidikan kepala desa berpengaruh negatif secara signifikan terhadap ketepatwaktuan penyampaian Laporan Per- 
tanggungjawaban Realisasi Pelaksanaan APBDesa. Hipotesis yang diajukan adalah jenjang pendidikan kepala desa berpengaruh positif terhadap variabel dependen, sedangkan hasil pengujian menunjukkan pengaruh yang ada adalah negatif. Dengan demikian hipotesis ketiga (H3) ditolak.

Menurut Bantel dan Jakson (1989) dalam Esteve et al. (2012), Hambrick dan Mason (1984) menyatakan bahwa tingkatan/jenjang pendidikan dari kepala desa mengindikasikan besarnya tingkatan pengetahuan dan dasar kemampuan dari manajer dan hal ini sangat mungkin mempengaruhi pengambilan keputusan strategis. Sebagian besar kepala desa mempunyai jenjang pendidikan Sekolah Menengah Atas (SMA) sebesar 58,97\%, sehingga kualitas tingkat kepatuhan terhadap hukum masih dalam taraf compliance atau menghindari sanksi atau hukuman. Menurut hasil penelitian Safitri dan Rahman (2013), menyatakan bahwa kualitas tingkat kepatuhan hukum pada jenjang pendidikan Sekolah Menengah Atas masih dalam taraf compliance atau menghindari sanksi atau hukuman. Dengan demikian, keputusan-keputusan yang dibuat oleh kepala desa sebagian besar hanya untuk menghindari hukuman atau sanksi.

Pengaruh yang diberikan oleh jenjang pendidikan kepala desa terhadap ketepatwaktuan penyampaian Laporan pertanggungjawaban realisasi pelaksanaan APBDesa sesuai dengan pendapat Pasaribu dan Tjen (2015) bahwa arah hubungan tingkat pendidikan seseorang bersifat negatif terhadap kepatuhan perpajakan. Hal ini menunjukkan bahwa semakin tinggi tingkat pendidikan seseorang, kepatuhannya malah menurun.

Dari penjelasan diatas, tingkat pendidikan kepala desa berpengaruh negatif secara signifikan terhadap ketepatwaktuan penyampaian Laporan pertanggungjawaban realisasi pelaksanaan APBDesa, dimana semakin tinggi tingkat pendidikan kepala desa maka kepatuhan terhadap peraturan yang ada semakin menurun. Hal ini mengakibatkan semakin tingginya jumlah penyampaian laporan yang terlambat.

Gender Kepala Desa dan Ketepatwaktuan
Penyampaian Laporan Pertanggungjawaban Realisasi Pelaksanaan APBDesa

Pengaruh variabel gender kepala desa (GDR) terhadap variabel dependennya sebagaimana hasil perhitungan yang disajikan dalam tabel 1 , nilai statistik Wald sebesar 7,952, bila dibandingkan dengan tabel Chi-Square untuk tingkat signifikan $5 \%$ atau 0,05 dan derajat bebas $(\mathrm{df})=1 \mathrm{di}-$ peroleh hasil 3,841 maka nilai hitung lebih besar dari nilai tabel. Hal tersebut menunjukkan bahwa variabel gender berpengaruh terhadap variabel dependen.

Berdasar hasil pengujian, Nilai B dari variabel gender sebesar 1,055. Oleh karena nilai B bersifat positif, maka variabel gender mempunyai hubungan positif terhadap variabel dependen. Sedangkan hasil pengujian variabel gender (GDR) memiliki nilai sig sebesar 0,004, nilai sig tersebut lebih kecil dari tingkat signifikansi yang ditentukan sebesar 0,05, menunjukkan bahwa variabel gender (GDR) memiliki pengaruh signifikan. Dari penjelasan tersebut, dapat disimpulkan bahwa gender (GDR) kepala desa berpengaruh positif secara signifikan terhadap ketepatwaktuan penyampaian Laporan Pertanggungjawaban Realisasi Pelaksanaan APBDesa. Hal ini menunjukkan bahwa hipotesis keempat (H4) diterima.

Hasil pengujian ini sesuai dengan penelitian yang dilakukan oleh CollinsDodd et al. (2004), Meier et al. (2006), Esteve et al. (2012) dan Jalbert et al. (2013) yang mengungkapkan bahwa gender dari manajer berpengaruh terhadap bagaimana manajer mengelola organisasi mereka. Collins-Dodd et al. (2004) mengungkapkan bahwa motivasi perempuan tentang karir dan keluarga memiliki hasil positif terhadap kinerja keuangan. Dengan besarnya motivasi yang dimiliki dan kemampuan perempuan dalam mengolah informasi yang diterima, maka hal itu berdampak pada ketepatan data yang dihasilkan sehingga laporan yang disusun menjadi akurat, minim kesalahan dan tepat waktu. Hal tersebut menunjukkan bahwa kepala desa dengan gender perempuan mampu menyampaikan laporan lebih tepat waktu bila dibandingkan dengan kepala desa yang laki-laki. Namun jumlah kepala desa perempuan dalam 
penelitian ini hanya sebanyak 37 orang dari 389 seluruh kepala desa atau sebesar 9,51\% saja.

\section{SIMPULAN}

Dari hasil pengujian terhadap empat variabel tersebut, menunjukkan terdapat 2 (dua) variabel independen yang berpengaruh terhadap penyampaian Laporan Pertanggungjawaban Realisasi Pelaksanaan APBDesa, yaitu jenjang pendidikan dan gender dari kepala desa.

Jenjang pendidikan berpengaruh negatif secara signifikan terhadap ketepatwaktuan penyampaian Laporan Pertanggungjawaban Realisasi Pelaksanaan APBDesa. Hal itu disebabkan oleh kepala desa yang menjadi objek penelitian sebanyak 58,97\% masih memiliki ijazah dengan jenjang pendidikan Sekolah Menengah Atas/sederajat. Sehingga kualitas tingkat kepatuhan terhadap hukum masih dalam taraf compliance atau menghindari sanksi atau hukuman yang menyebabkan keputusan-keputusan yang dibuat oleh kepala desa sebagian besar hanya untuk menghindari hukuman atau sanksi.

Sedangkan gender berpengaruh positif secara signifikan terhadap ketepatwaktuan penyampaian Laporan Pertanggungjawaban Realisasi Pelaksanaan APBDesa. Besarnya motivasi perempuan dan kemampuan perempuan dalam mengolah informasi yang diterima, berdampak pada ketepatan data yang dihasilkan sehingga laporan yang disusun menjadi akurat dan minim kesalahan. Hal tersebut menunjukkan bahwa kepala desa dengan gender perempuan mampu menyampaikan laporan lebih tepat waktu bila dibandingkan dengan kepala desa yang laki-laki.

Berdasarkan hasil penelitian, pengaruh kepala desa terhadap ketepatwaktuan penyampaian laporan sangat kecil hanya sebesar 5,7 persen. Hal ini menunjukkan bahwa terdapat faktor-faktor lain yang memiliki pengaruh lebih besar terhadap ketepatwaktuan pelaporan tersebut.

\section{SARAN}

Saran yang diberikan untuk pengembangan penelitian selanjutnya mengenai ketepatwaktuan penyampaian laporan per- tanggungjawaban realisasi pelaksanaan APBDesa dalam enelitian selanjutnya sebaiknya menggunakan atau menambah variabel lain yang mungkin mempengaruhi ketepatwaktuan penyampaian laporan pertanggungjawaban realisasi pelaksanaan APBDesa seperti pemahaman sistem informasi dan regulasi pemerintah. Memperbesar perbandingan objek penelitian pada variabel gender agar lebih menggambarkan kondisi sebenarnya.

\section{DAFTAR PUSTAKA}

Andriani, W. 2010. Pengaruh Kapasitas Sumber Daya Manusia dan Pemanfaatan Teknologi Informasi terhadap Keterandalan dan Ketepatwaktuan Laporan Keuangan Pemerintah Daerah (Studi pada Pemerintah Daerah Kab. Pesisir Selatan). Jurnal Akuntansi dan Manajemen, 5 (1): 69-80.

Ariyanti, W.D. 2012. Pengaruh Kompensasi dan Motivasi Kerja terhadap Loyalitas Pegawai Salah Satu Perusahaan Swasta: Studi terhadap Persepsi Pegawai di Salah satu Perusahaan Swasta. Tesis, Universitas Pendidikan Indonesia, Bandung.

Arsyiati, D. dan M.A. Djalil. 2008. Pengaruh Kualitas Sumber Daya Manusia dalam Pengelolaan Keuangan terhadap Kualitas Pertanggungjawaban Keuangan PNBP dalam Upaya Meningkatkan Kinerja Instansi pada Universitas Syah Kuala. Jurnal Telaah dan Riset Akuntansi, 1(1): 29-49.

Collins-Dodd, C., I.M. Gordon dan C. Smart. 2004. Further Evidence on the Role of Gender in Financial Performance. Journal of Small Business Management, 42 (4): 395-417.

DJP (Direktorat Jenderal Pajak). 2015. Informasi APBN 2016. Diakses dari: www.pajak.go.id.

Esteve, M. et al. 2012. Organizational Collaboration In The Public Sector: Do Chief Executives Make a Difference? Journal of Public Administration Research and Theory, 23 (4): 927-952.

Fontanella, A. 2010. Analisis Pengaruh Latar Belakang Pendidikan dan Pengetahuan Akuntansi Pengguna terhadap Pemanfaatan Laporan Keuangan Pemerintah Daerah. Jurnal Akuntansi \& Manajemen, 5 (2): 22-30.

Ghozali, I. 2006. Aplikasi Analisis Multivariate dengan Program SPSS. Edisi Keempat. Semarang: Badan Penerbit Universitas Diponegoro. 
Gomes, R.G., S. Alfinito dan P.H.M. Albuquerque. 2013. Analyzing Local Government Financial Performance: Evidence from Brazilian Municipalities 2005-2008. Revista de Administracao Contemporanea, 17 (6): 704-719.

Hambrick, D. dan Mason. 1984. Upper Echelons: The Organization as a Reflection of Its Top Managers. The Academy of Management Review, 9 (2): 193-206.

Hamzah, A. 2015. Tata Kelola Pemerintahan Desa Menuju Desa Mandiri, Sejahtera dan Partisipatoris. Surabaya: Pustaka

Jalbert, T., M. Jalbert dan K. Furumo. 2013. The Relationship Between CEO Gender, Financial Performance, and Financial Management. Journal of Business and Economics Research, 11 (1): 25-34.

Kemendagri (Kementerian Dalam Negeri). 2007. Peraturan Menteri Dalam Negeri Nomor 37 Tahun 2007 tentang Pedoman Pengelolaan Keuangan Desa.

2014. Peraturan Menteri Dalam Negeri Nomor 113 Tahun 2014 tentang Pengelolaan Keuangan Desa. . 2015. Peraturan Menteri Dalam Negeri Nomor 39 Tahun 2015 tentang Kode dan Data Wilayah Administrasi Pemerintahan.

Peraturan Menteri Dalam Negeri Nomor 56 Tahun 2015 tentang Kode dan Data Wilayah Administrasi Pemerintahan.

Kemenkeu (Kementerian Keuangan). 2016. Peraturan Menteri Keuangan Nomor 49/PMK.07/2016 tentang Tata Cara Pengalokasian, Penyaluran, Penggunaan, Pemantauan dan Evaluasi Dana Desa.

KPK. 2015. Laporan Hasil Kajian Pengelolaan Keuangan Desa: Alokasi Dana Desa dan Dana Desa.

Kusuma, H. 2015. Waduh, Dana desa Tahap Tiga Terancam Batal!. Diakses dari: O k e z o n e.com. h t t p:// e conomy.okezone.com / read/2015/10/21/20/1235765/ waduh-dana-desa-tahap-tigaterancam-batal pada 6 Januari 2016.

Lubis, A.I. 2010. Akuntansi Keperilakuan. Jakarta: Salemba Empat.

Meier, K.J., L.J.Jr. O'Toole dan H.T. Goerdel. 2006. Management Activity and Program Performance: Gender as Management Capital. Public Administration Review, 66 (1): 24-36.

Pasaribu, G.F. dan C. Tjen. 2015. Dampak
Faktor-Faktor Demografi terhadap Kepatuhan Perpajakan di Indonesia. Berkala Akuntansi dan Keuangan Indonesia, 1 (2): 145-162.

Patikab.go.id. 2016. 401 Desa di Pati Siap Kelola Kembali Dana Desa. Diakses dari: $\quad$ https://patikab.go.id/v2/ id/2016/04/29/401-desa-di-pati-siapkelola-kembali-dana-desa pada 1 Februari 2016.

Puspitawati, H. 2012. Gender dan Keluarga: Konsep dan Realita di Indonesia. Bogor: PT IPB Press.

Republik Indonesia. 2003. Undang-Undang Nomor 20 Tahun 2003 tentang Sistem Pendidikan Nasional. 2004. Undang-Undang Nomor 32 Tahun 2004 tentang Pemerintah Daerah

. 2014. Peraturan Pemerintah Republik Indonesia Nomor 43 Tahun 2014 tentang Peraturan Pelaksanaan Undang-Undang Nomor 6 Tahun 2014 tentang Desa.

2014. Peraturan Pemerintah Nomor 60 Tahun 2014 tentang Dana Desa yang Bersumber dari APBN. 2014. Undang-Undang Nomor 6 Tahun 2014 tentang Desa. 2015. Peraturan Presiden Republik Indonesia Nomor 137 Tahun 2015 tentang Rincian Anggaran Pendapatan dan Belanja Negara Tahun Anggaran 2016.

Robbins S.P. dan Judge. 2007. Perilaku Organisasi. Jakarta: Salemba Empat.

Safitri, A. dan T. Rahman. 2013. Tingkat Kepatuhan Hukum Siswa SMA Kartika IV-3 Surabaya terhadap Etika Berlalulintas menurut Undang-Undang Nomor 22 Tahun 2009. Kajian Moral dan Kewarganegaraan, 3 (1): 485-499.

Sari, S.P. dan B. Witono. 2014. Keterandalan dan Ketepatwaktuan Pelaporan Keuangan Daerah Ditinjau dari Sumber Daya Manusia, Pengendalian Internal dan Pemanfaatan Teknologi Informasi. Seminar Nasional dan Call for Paper: Research Methods and Organizational Studies, ISBN: 978-60270429-1-9, 418-425.

Sekaran, U. dan R. Bougie. 2013. Research Methods for Business. United Kingdom: Jhon Wiley \& Sons Ltd.

Sugiyono. 2014. Metode Penelitian Pendidikan Pendekatan Kuantitatif, Kualitatif dan R\&D. Bandung: Alfabeta.

Thenu, Stefy. 2016. Penyaluran Dana Desa, Perangkat Desa Takut Kena Masalah Hukum. Diakses dari: http:// $\mathrm{w} w \mathrm{w}$. b e rit a s a t u . c o m / 
nusantara/317678-penyaluran-danadesa-perangkat-desa-takut-kenamasalah-hukum.html pada 6 Januari 2016.

Winidyaningrum, C. dan Rahmawati. 2010. Pengaruh Sumberdaya Manusia dan Pemanfaatan Teknologi Informasi terhadap Keterandalan dan Ketepatwaktuan Pelaporan Keuangan Pemerintah Daerah dengan Variabel Intervening Pengendalian Intern
Akuntansi. Simposium Nasional Akuntansi XIII, Purwokerto, Indonesia.

Wulanda, R., Brasit dan Hamid. 2013. Pengaruh Tingkat Pendidikan dan Pelatihan, Motivasi dan Budaya Organisasi terhadap Kinerja Pegawai Negeri Sipil Sekretariat Daerah Kabupaten Wakatobi. Tesis, Universitas Hasanuddin, Makassar. 